\title{
Demandasaurus darwini, a new rebbachisaurid sauropod from the Early Cretaceous of the Iberian Peninsula
}

Fidel Torcida Fernández-Baldor, José Ignacio Canudo, Pedro Huerta, Diego Montero, Xabier Pereda Suberbiola, and Leonardo Salgado

Acta Palaeontologica Polonica 56 (3), 2011: 535-552 doi: http://dx.doi.org/10.4202/app.2010.0003

A new medium-sized rebbachisaurid sauropod from the Castrillo la Reina Formation (Upper Barremian-Lower Aptian) in Burgos Province, Demandasaurus darwini gen. et sp. nov., is described. It is known from an incomplete but associated skeleton that includes cranial and post-cranial remains. Demandasaurus darwini gen. et sp. nov. presents 9 autapomorphies in the teeth and vertebrae. Demandasaurus is the first diplodocoid sauropod described from the Cretaceous of the Iberian Peninsula. Its inclusion in the Rebbachisauridae is well supported by our phylogenetic hypothesis, which situates it as a sister group of Nigersaurus from the Aptian of Niger, with which it shares various synapomorphies. The discovery of Demandasaurus provides further evidence of the sporadic use of the Apulian Route by dinosaurs during the Early Cretaceous for moving between the south of Europe (Laurasia) and the north of Africa (Gondwana).

Key words: Sauropoda, Rebbachisauridae, systematic, palaeobiogeography, Early Cretaceous, Spain.

Fidel Torcida Fernández-Baldor [fideltorcida@ hotmail.com], Pedro Huerta [phuerta@ usal.es ], and Diego Montero [monteropodo@ hotmail.com], Museo de Dinosaurios de Salas de los Infantes, 09600 Salas de los Infantes, Burgos, Spain and Colectivo Arqueológico-Paleontológico Salense (CAS) Plaza Jesús Aparicio 9, 09600 Salas de los Infantes, Burgos, Spain; José Ignacio Canudo [jicanudo@unizar.es], Grupo Aragosaurus-IUCA, Paleontología, Facultad de Ciencias, Universidad de Zaragoza, Pedro Cerbuna 12, 50009 Zaragoza. Spain; Xabier Pereda Suberbiola [xabier.pereda@ehu.es ], Universidad del País Vasco/EHU, Facultad de Ciencia y Tecnología, Estratigrafía y Paleontología, Apartado 644, 48080 Bilbao, Spain; Leonardo Salgado [lisalgado@uncoma.edu.ar], INIBIOMA-CONICET, Museo de Geología y Paleontología, Universidad Nacional del Comahue, Buenos Aires 1400, 8300 Neuquén, Argentina. 
This is an open-access article distributed under the terms of the Creative Commons

Attribution License (for details please see creativecommons.org), which permits unrestricted use, distribution, and reproduction in any medium, provided the original author and source are credited.

Faril text $(830.1 \mathrm{kB})$ 